\title{
Why do part-time workers invest less in human capital than full-timers?
}

Citation for published version (APA):

Nelen, A. C., \& de Grip, A. (2008). Why do part-time workers invest less in human capital than full-timers? Researchcentrum voor Onderwijs en Arbeidsmarkt, Faculteit der Economische Wetenschappen. ROA Research Memoranda No. 4 https://doi.org/10.26481/umaror.2008004

Document status and date:

Published: 01/01/2008

DOI:

10.26481/umaror.2008004

Document Version:

Publisher's PDF, also known as Version of record

\section{Please check the document version of this publication:}

- A submitted manuscript is the version of the article upon submission and before peer-review. There can be important differences between the submitted version and the official published version of record.

People interested in the research are advised to contact the author for the final version of the publication, or visit the DOI to the publisher's website.

- The final author version and the galley proof are versions of the publication after peer review.

- The final published version features the final layout of the paper including the volume, issue and page numbers.

Link to publication

\footnotetext{
General rights rights.

- You may freely distribute the URL identifying the publication in the public portal. please follow below link for the End User Agreement:

www.umlib.nl/taverne-license

Take down policy

If you believe that this document breaches copyright please contact us at:

repository@maastrichtuniversity.nl

providing details and we will investigate your claim.
}

Copyright and moral rights for the publications made accessible in the public portal are retained by the authors and/or other copyright owners and it is a condition of accessing publications that users recognise and abide by the legal requirements associated with these

- Users may download and print one copy of any publication from the public portal for the purpose of private study or research.

- You may not further distribute the material or use it for any profit-making activity or commercial gain

If the publication is distributed under the terms of Article $25 \mathrm{fa}$ of the Dutch Copyright Act, indicated by the "Taverne" license above, 


\title{
Why do Part-Time Workers invest less in Human Capital than Full-Timers?
}

\author{
Annemarie Nelen \\ Andries de Grip \\ ROA-RM-2008/4 \\ July 08
}

Research Centre for Education

and the Labour Market

P.O. Box 616

6200 MD Maastricht

The Netherlands

E-mail: $\quad$ secretary@roa.unimaas.nl

Internet: $\quad$ www.roa.unimaas.nl

Maastricht University

Faculty of Economics and Business Administration 
The ROA Research Memorandum Series was created in order to make research results available for discussion, before those results are submitted for publication in journals.

Sec08.111.pdf 
ROA-RM-2008/4 » http://www.roa.unimaas.nl/resmem.htm

\section{Abstract}

\section{Why do Part-Time Workers invest less in Human Capital than Full- Timers? ${ }^{1}$}

We analyze whether lower investments in human capital of part-time workers are due to workers' characteristics or human resource practices of the firm. We focus on investments in both formal training and informal learning. Using the Dutch Life-Long-Learning Survey 2007, we find that part-time workers have different determinants for formal training and informal learning than full-time workers. The latter benefit from firms' human resource practices such as performance interviews, personal development plans and feedback. Part-time workers can only partly compensate the lack of firm support when they have a high learning motivation and imagination of their future development.

JEL codes: J22, J24, M53

Keywords: Training, Learning on-the-job, Part-Time Work

Annemarie Nelen

ROA

P.O. Box 616

6200 MD Maastricht

a.nelen@roa.unimaas.nl
Andries de Grip

ROA

P.O. Box 616

6200 MD Maastricht

a.degrip@roa.unimaas.nl

1. The authors thank Lex Borghans and Arnaud Dupuy for useful suggestions and Ben Kriechel, Thomas Dohmen, Hans Heijke and Didier Fouarge for their comments on earlier versions of this paper. 



\section{Introduction}

Several studies have found that part-time workers invest less in formal training than full-time workers (e.g. Maximiano \& Oosterbeek, 2007; Greenhalgh \& Mavrotas, 1996). This is an important finding because continuous upgrading of workers' skills is often assumed to be necessary to keep up with competitors. Human capital theory explains the lower training participation of part-time workers by lower incentives to invest in their human capital investments because part-timers have less working time to benefit from training investments. This holds both for the worker himself and for the employer. However, in human capital literature there is no evidence on how this is effectuated. In this paper, we analyze the differences between part-time and full-time workers in the determinants of both formal training and informal learning. Building on human capital theory, we focus on determinants related to both the demand and the supply side of the labour market.

We contribute to the existing literature in two ways. First, there are hardly any studies that analyze to what extent it is the firms or the part-time workers themselves who are responsible for the lower investment in human capital of part-time workers. The only exception we know is Maximiano \& Oosterbeek (2007), which focuses on participation in formal training. We analyze to what extent the differences in both formal training and informal learning patterns of part-time workers are demand or supply lead by distinguishing between workers' psychological characteristics and firms' human resource practices. Second, we broaden the literature on Human Resource Management (HRM), which generally relates different packages of human resource practices to productivity or job turnover (e.g. Lynch \& Black, 1998; Ichniowski, Shaw \& Prennushi 2003). In this paper, we relate human resource practices to investments in both formal training and informal learning.

For our analysis, we use data of the Dutch Life-Long-Learning Survey 2007. This survey focuses on knowledge development and training behaviour during the lifecycle. We estimate separate human capital investment equations for part-time and full-time workers. To control for selectivity into employment status we use a Heckman-type selection correction model. We find that determinants of formal training and informal learning are different for part-time and full-time workers. In contrast to Maximiano \& Oosterbeek (2007), we find that lower human capital investments for part-time workers are mainly demand lead. The human capital investment behaviour of part-time workers is influenced most by psychological 
characteristics such as imagination of future development, whereas full-time workers are particularly positively influenced by their firms' human resource practices such as performance interviews, personal development plans and feedback.

The structure of this paper is as follows: The next section gives a brief review of the relevant literature. Section 3 describes the data and gives some descriptive statistics. In Section 4, we describe the estimation method and show the main results. Section 5 concludes.

\section{Related literature}

Human capital theory states that both firms and workers weigh the costs and benefits of investing in training (Becker, 1964). Since training participation lowers current productivity and increases productivity after training, the working time during which workers can benefit from higher future earnings is important for the decision to invest. As part-timers work by definition fewer hours, they are expected to participate less in training and spend less time on informal learning because they have less time to benefit from their investments, whereas the investment costs of a particular training are the same for part-time and full-time workers. For the same reason, employers will benefit more from investing in full-time workers than in part-time workers. The human capital argument holds for both formal training and informal learning. Whereas investments in formal training refer to both direct and indirect costs, informal learning still requires indirect investment costs in the form of foregone productivity.

Greenhalgh and Mavrotas (1996) found that both part-time men and part-time women have a lower training probability than their full-time counterparts, whereas Maximiano and Oosterbeek (2007) more specifically found that workers' training probability increases when contractual working hours increase. The latter also provides a framework in which it is possible to differentiate whether training participation is caused by the employee or employer. One of their conclusions is that part-time workers participate less in training as a result of both the workers and the firms being less willing to invest. However, Maximiano and Oosterbeek (2007) did not analyze the underlying determinants of the difference in training investments. 
Several streams of literature deal with determinants of workers' human capital investments. This might help to explain the willingness of employees to invest in human capital. The generally analyzed determinants of workers' training include age, level of education, gender, marital status and number of children (e.g. Greenhalgh and Mavrotas, 1996). Furthermore, individual discount rates might be related to educational participation Becker (1964). Individuals with a high discount rate are expected to invest less in their human capital. However, empirical evidence for this result is scarce (e.g. Fersterer \& Winter-Ebmer, 2003; DellaVigna \& Paserman, 2005; Munasinghe \& Sicherman, 2000). A more recent phenomenon in economic literature: the possible relationship between psychological characteristics which relate to time preferences and investments in human capital. Golsteyn (2007) analyzed the effects of imagination on investments in human capital. He found that workers with more imagination invest more in their skill deficiencies. Whereas Golsteyn (2007) related imagination to the quality of human capital investments, we will relate imagination to the quantity of human capital investments. In psychological literature, the emphasis is on the relationship between workers motivation for learning and training participation. Birdi, Allan and Warr (1997) found a positive relation between learning motivation and training participation ${ }^{1}$.

The literature on HRM focuses on various human resource practices that express the willingness of firms to invest in their employees, such as performance interviews, personal development plans and career plans. However, most of the HRM literature analyzes the relationship between human resource practices and outcomes such as productivity and job turnover (for an overview, see Wood, 1999). Human resource practices of firms aim at maintaining and upgrading the skills of their workers. Since these human resource practices are often complementary and performance levels of firms probably do not depend on single human resource practices, most of the existing literature analyzes the role of a set of related human resource practices (e.g. MacDuffie, 1995; Arthur, 1994).

There are hardly any studies that analyze the consequences of HRM on the human capital investments of employees. The analysis of Lynch and Black (1998) on the relation between high performance workplaces (HPW) and training participation, is an exception. They found a positive correlation between HPW and the proportion of workers trained. In their paper, HPW are characterized by Total Quality Management, the use of job rotation and teams. In HPW literature there seems to be no single accepted definition for describing what characterizes such workplaces (as pointed out by Osterman, 1994). However, most studies 
characterize HPW by autonomous core workers who co-operate in self-responsible teams (e.g. Youndt et al., 1996). Moreover, to keep workers motivated, HPW must offer incentive payments (e.g. Becker \& Huselid, 1998).

Another HRM-related determinant of human capital investments of workers is feedback. Facteau et al. (1995) analyzed the role of social support variables (different types of colleague feedback) on the spill-over of formal to informal training. They found a positive relation between subordinate, peer and top management support and perceived training transfer. The way in which feedback is given may also influence training behaviour. Prospect theory argues that perceived losses feel much worse than gains of the same size feel good (Kahneman \& Tverksy, 1979). An application of this theory is the analysis by McFarland \& Miller (1994), which showed that recipients of feedback have more positive reactions and report higher ability levels when they focus on the positive features of feedback compared to the negative features. They separated these two forms of feedback by comparing the number of other workers in the same firm who performed better or worse than they did themselves. Thaler (1999) showed that the difference in perceived losses and gains can in turn influence decisions substantially. As far as we know, the effects of positive and negative feedback on human capital investments at the work floor have never been analyzed.

\section{Data and Descriptive Statistics}

For our analyses on the relationship between part-time employment and human capital investments, we use the Dutch Life-Long-Learning Survey 2007. This survey is a supplement to the basic questionnaires of the DNB Household Panel. This panel consists of 2,361 individuals who form a representative sample of the Dutch population of 16 years and older. Supplements to this panel provide information on specific topics. The Life-Long-Learning Survey focuses on knowledge development and training behaviour during the lifecycle. The response of this survey is equal to 1,775 respondents (which is approximately 75 percent).

For our analysis, we only use information on employed persons. This leaves us with a data set of 864 respondents. We furthermore divide the sample into part-time and full-time workers based on actual working hours ${ }^{2}$. We defined workers who work less than 33 working hours per week as part-time workers. There are different definitions of part-time work in the 
Netherlands (cf. De Grip et al., 1997). The definition is in fact occupation-related. Statistics Netherlands (CBS) defines part-time workers as workers who work more than 12 and less than 35 hours per week. Since this definition qualifies full-time shift workers in some sectors of industry as part-time workers and excludes those who work less than 12 hours per week, we did not use this definition. Another difference with our definition is that Statistics Netherlands includes all pupils and students who work besides their studies. The DNB Household Survey takes 32 hours per week as the threshold ${ }^{3}$. We decided to set the threshold at 33 hours per week so that people who work 4 days a week (32 hours) are defined as parttime workers. The sample counts 51 persons who work 32 hours per week, so we assigned 32 persons to the part-time group, who would have been defined as full-time workers by the DNB Household Survey. Those working 33 hours per week or more are defined as full-time workers.

The disadvantage of using actual working hours is that some respondents reported extreme numbers of working hours (e.g. 82). We therefore truncate the hours worked of 43 persons who reported to work more than 50 hours per week. The sample consists of 270 part-time workers (55 men and 215 women) and 594 full-time workers (444 men and 150 women). The percentage of part-time workers is about 31 percent, which is 6 percentage points lower than the percentage of part-time workers in the Netherlands in 2005 as measured in the Labor Force Survey.

From the Life-Long-Learning Survey, we derive the following variables:

\section{Human Capital Investments}

Human capital investments are divided into two types: formal training and informal learning. To measure formal training, we created two variables: (1) Training participation as a dummy variable which is equal to one if the respondent attended one or more trainings during the last two years, and zero otherwise; (2) The number of courses and trainings in which the respondent participated in the last two years. 
Figure 1. Training participation by employment status

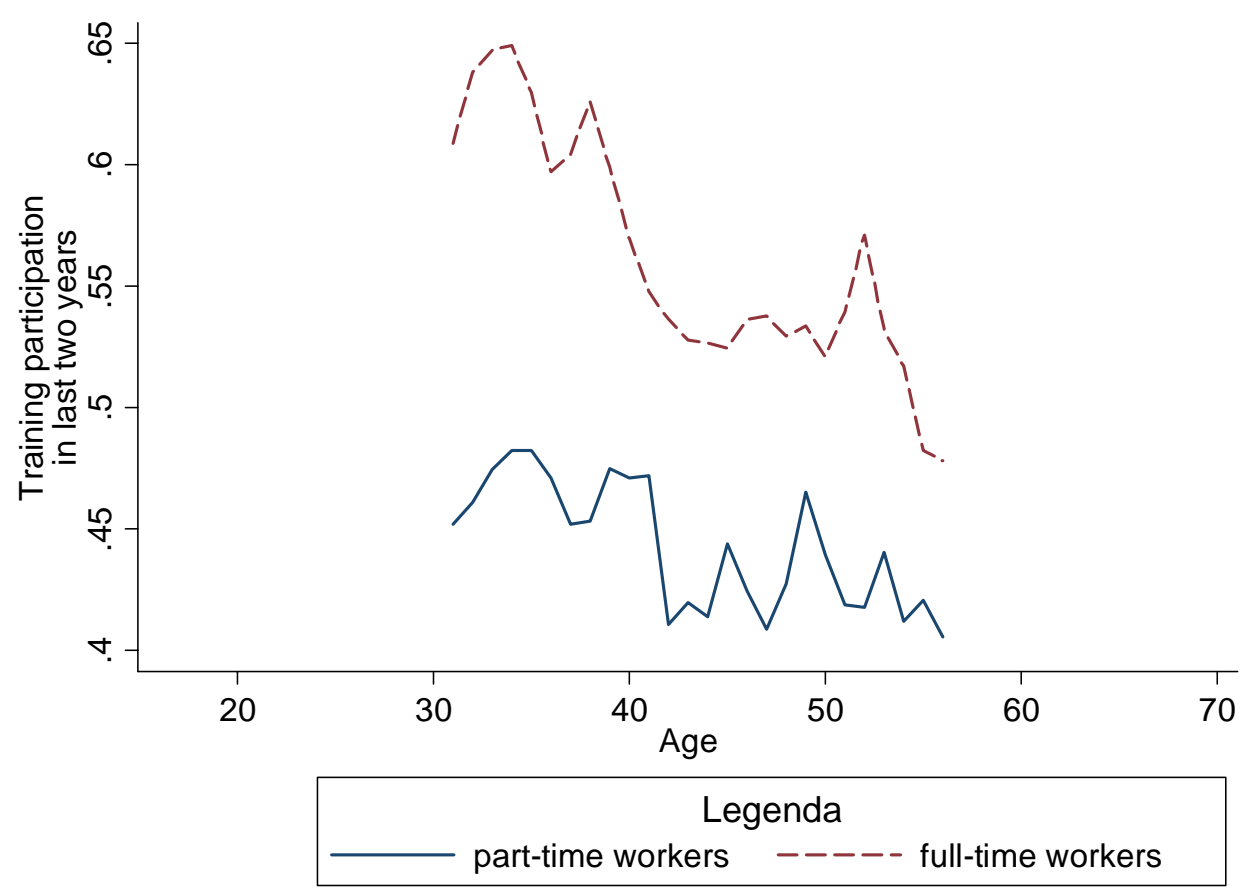

Source: Dutch Life-Long-Learning Survey 2007

Note: Figure is based on 11-year moving averages (computed over the age-interval 5 year above and 5 year below a certain age)

Figure 1, shows training participation for part-time and full-time workers over the lifecycle (based on 11-year moving averages). Two features in line with human capital theory arise from the figure. First, part-time workers participate less in training than full-time workers at all ages. Second, the training gap is largest for younger workers: While 45 percent of the 30 year old part-time workers attended at least one training in the last two years, more than 60 percent of the full-timer workers of the same age participated. Over the lifecycle this difference declines. Table 2 shows that 57 percent of the full-time workers participated in one or more formal training courses in the last two years, compared to only 45 percent of the parttime workers. The table also shows that part-time workers participated on average in 1 course, whereas full-time workers attended in 1.4 courses in the last two years.

Even though economic literature has focused mainly on formal training, recent research (Borghans, Golsteyn \& De Grip, 2007) found that by far the largest part of the time workers invest in their human capital development refers to informal learning. Informal learning is defined as time spent on tasks from which one can learn. The question used is: What percentage of your working time do you spend on tasks from which you can learn? Table 2 
shows that part-time and full-time workers spend about the same fraction of their working time on tasks from which they can learn. On average, workers report to spend about 28 percent of working time on informal learning ${ }^{4}$. For our analysis we use informal learning as a fraction of working time (dividing the percentage by 100).

However, because of the difference in working hours between part-time and full-time workers, part-timers score lower on informal learning measured in hours. Figure 2 shows informal learning over the lifecycle. It shows the same patterns as Figure 1. Again, we see that part-time workers invest less in their human capital development than full-time workers. Whereas 30-year old part-time workers spend on average about 8.5 hours on tasks from which they can learn, full time workers spend almost 14 hours on informal learning per week. Furthermore, a negative relationship exists between investments in informal learning and age. This is exactly what we expect, since older workers, on average, know more and therefore have less learning opportunities from tasks they perform.

\section{Figure 2. Informal learning in hours of working time by employment status}

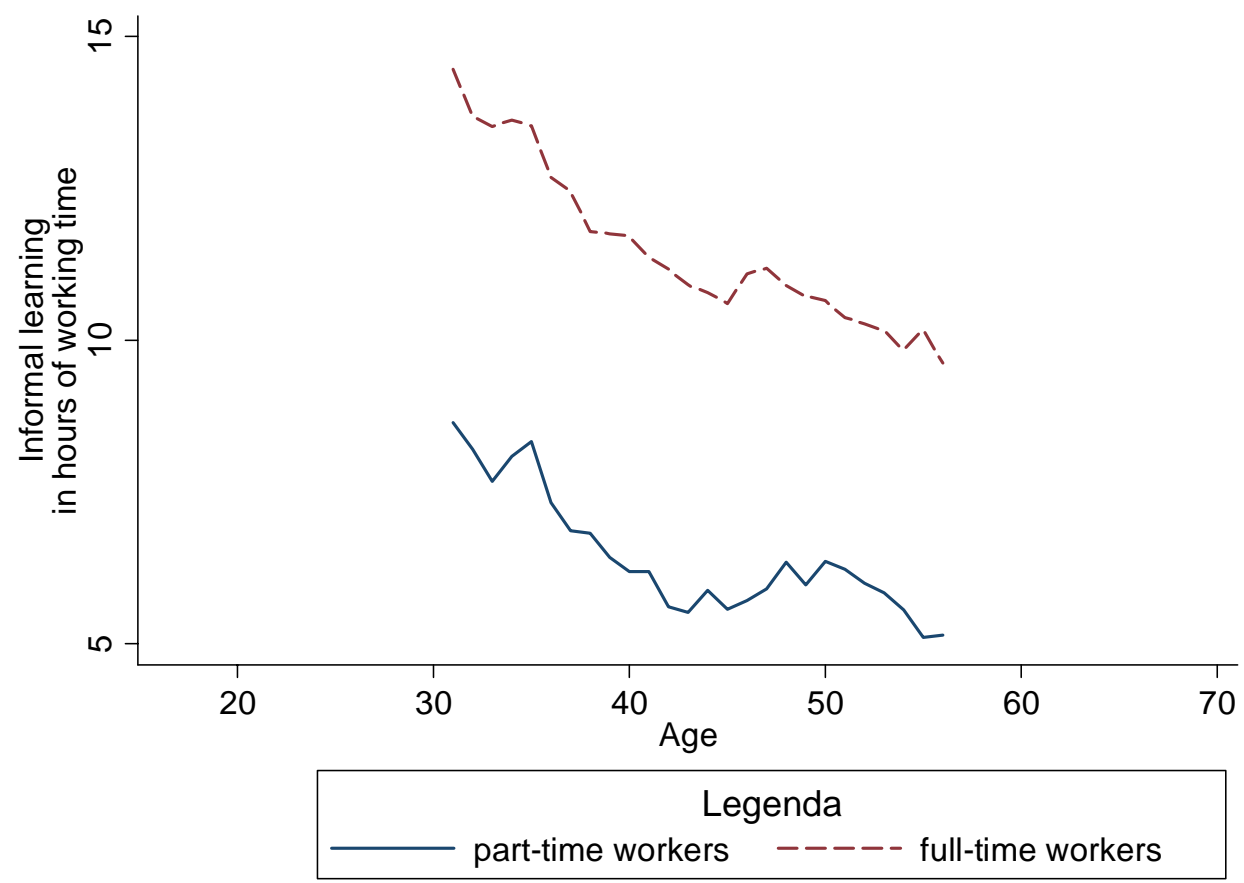

Source: Dutch Life-Long-Learning Survey 2007

Note: Figure is based on 11-year moving averages (computed over the age-interval 5 year above and 5 year below a certain age) 


\section{Explanatory variables}

The explanatory variables are divided in two groups: psychological characteristics and HRMrelated variables. Table 1 shows which questions are used to construct the variables. Questions that are asked on a 7-points Likert scale are standardized for the analyses (mean is equal to zero and standard deviation is equal to one). In Table 2, which gives the mean and standard deviations of the variables used, these variables are reported in their original 7points Likert scale.

We include two psychological characteristics of workers: imagination and learning motivation. Both psychological characteristics are asked on a 7-points Likert scale. We measure a person's imagination by the question To what extent do you have a clear idea about how you would like to develop yourself in the next few years. Learning motivation is measured by a question in which respondents state how much they like learning new things. The two psychological characteristics seem to be distributed fairly equally between part-time and full-time workers, as can be seen in Table 2 .

Since we have employee data, we do not have an exact measure for the firms' willingness to invest. However, we use HRM practices to proxy the willingness of firms to invest. These human resource practices included in the analysis are divided into three subgroups: (1) human resource development practices, (2) HPW and (3) feedback. First, we include the practices related to human resource development: performance interviews, personal development plans and career plans. The respondents were asked whether or not their employer pays attention to their performance and/or career development by means of these practices. Table 2 shows that the provision of human resource development practices for parttime workers is of about equal size as for full-time workers. Second, we include characteristics of $H P W$ : team meetings, autonomy and performance payments. Respondents were asked to state whether or not their employer organizes team meetings and pays them according to their performance. To determine the level of autonomy, respondents could state on a 7-points Likert scale to what extent they agree with the statement I have a great deal of freedom to decide how to perform tasks. Table 2 shows that part-time workers have slightly more team meetings than full-timers, and about 6 percentage points less autonomy. The difference between part-time and full-time workers is largest with respect to performance payments. One third of the full-time workers has performance payments, compared to only 14 percent of the part-time workers. Third, we focus on different kinds of feedback: positive 


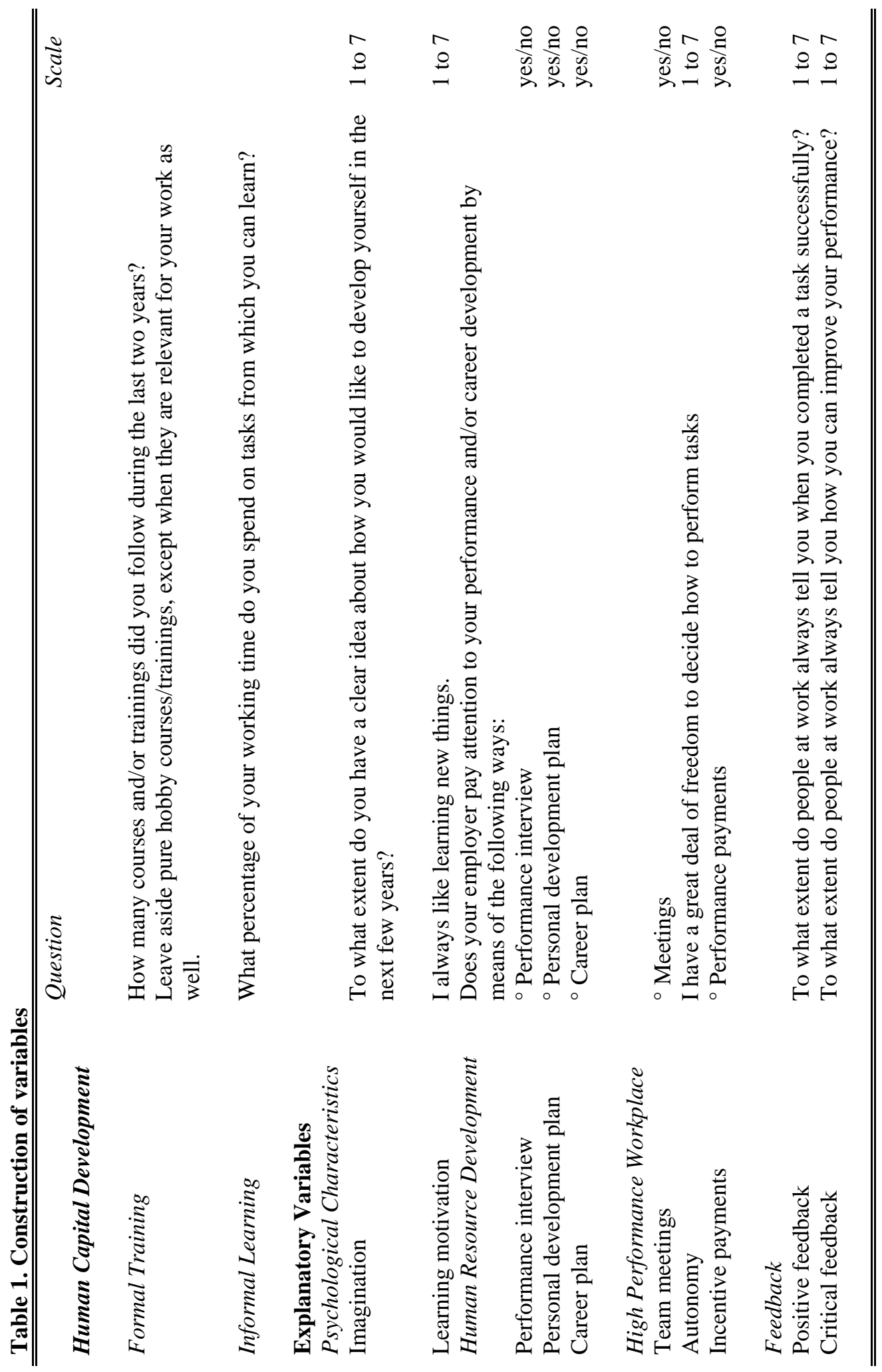


Table 2. Characteristics by employment status

\begin{tabular}{|c|c|c|c|c|}
\hline \multirow{4}{*}{$\begin{array}{l}\text { Human Capital Developmen } \\
\text { Formal Training }\end{array}$} & \multicolumn{2}{|c|}{ Part-time workers } & \multicolumn{2}{|c|}{ Full-time workers } \\
\hline & \multicolumn{2}{|c|}{$\begin{array}{ll}\text { mean } & \text { standard } \\
& \text { deviation }\end{array}$} & \multicolumn{2}{|c|}{$\begin{array}{ll}\text { mean } & \begin{array}{l}\text { standard } \\
\text { deviation }\end{array}\end{array}$} \\
\hline & & & & \\
\hline & & & & \\
\hline Training participation & 0.452 & 0.499 & 0.569 & 0.496 \\
\hline Number of training courses & 1.052 & 1.640 & 1.431 & 2.129 \\
\hline \multicolumn{5}{|l|}{ Informal Learning } \\
\hline in hours per week & 6.861 & 7.103 & 11.927 & 11.823 \\
\hline in \% & 27.848 & 27.143 & 28.170 & 27.041 \\
\hline \multicolumn{5}{|l|}{ Explanatory Variables } \\
\hline \multicolumn{5}{|l|}{ Psychological Characteristics } \\
\hline Imagination * & 4.493 & 1.587 & 4.505 & 1.566 \\
\hline Learning motivation * & 5.741 & 1.080 & 5.727 & 1.068 \\
\hline \multicolumn{5}{|l|}{ Human Resource Development } \\
\hline Performance interview & 0.819 & 0.386 & 0.818 & 0.386 \\
\hline Personal development plan & 0.419 & 0.494 & 0.433 & 0.496 \\
\hline Career plan & 0.204 & 0.404 & 0.215 & 0.412 \\
\hline \multicolumn{5}{|l|}{ High Performance Workplace } \\
\hline Team meetings & 0.826 & 0.380 & 0.806 & 0.395 \\
\hline Autonomy * & 5.056 & 1.634 & 5.458 & 1.432 \\
\hline Incentive payments & 0.144 & 0.352 & 0.335 & 0.472 \\
\hline \multicolumn{5}{|l|}{ Feedback } \\
\hline Positive feedback * & 3.400 & 1.693 & 3.172 & 1.591 \\
\hline Critical feedback * & 3.207 & 1.574 & 3.042 & 1.477 \\
\hline \multicolumn{5}{|l|}{ Control Variables } \\
\hline Age & 43.448 & 10.745 & 43.428 & 10.287 \\
\hline Female & 0.796 & 0.403 & 0.253 & 0.435 \\
\hline Years of education & 14.598 & 2.423 & 15.180 & 2.351 \\
\hline Hours & 24.189 & 6.780 & 41.887 & 6.415 \\
\hline Partner & 0.844 & 0.363 & 0.736 & 0.441 \\
\hline Number of children & 1.233 & 1.101 & 0.998 & 1.171 \\
\hline
\end{tabular}

Note: * variables are on a 7-points Likert scale

and critical feedback. Positive feedback is measured by the statement People at work always tell me when I completed a task successfully. Critical feedback is measured by At work people always tell me how I can improve my performance. On a 7-points Likert scale, respondents could state to what extent they agree with these statements. It is remarkable to see that parttimers seem to get feedback of both types more often. 
Finally, we include several control variables: respondent's age, gender, years of completed education, hours ${ }^{5}$, partner, the number of children and industry ${ }^{6}$. Gender and having a partner are included as dummy variables which equal one if the respondent is feminine and has a partner respectively, and zero otherwise. 13 industry dummies are included, based on the classification used in the DNB Household Survey ${ }^{7}$. One can clearly see from Table 2 that almost 80 percent of the part-time workers are women, compared to 25 percent of the fulltime employed. On average, part-time workers also have more children than full-time workers.

\section{Empirical Strategy and Results}

\section{Empirical Strategy}

We will analyze whether the factors that determine the learning behaviour of part-time workers are different from the factors that determine the human capital investments of fulltime workers. As there may be variables which determine both the choice for part-time or full-time employment and the human capital investment decisions, we use the two-step Heckman-type selection correction method $^{8}$. Two-step estimations are preferred over the more direct Maximum Likelihood (ML) estimation, because the former is less sensible to inconsistency ${ }^{9}$.

In the first step we estimate the following selection equation:

$$
\text { EmploymentStatus }_{i}=\alpha_{0}+\beta_{1} \text { age }_{i}+\gamma_{2} \text { female }_{i}+\delta_{3} \text { yeduc }_{i}+\varsigma_{4} \text { FTpartner }_{i}+\eta_{5} \text { kids }_{i}+\varepsilon_{i}
$$

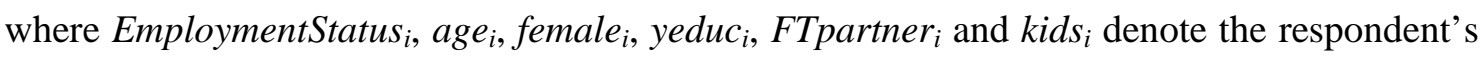
employment status (part-time versus full-time), age, gender, years of completed education, the full-time status of the partner and the number of children for person $i$ respectively. As EmploymentStatus $_{i}$ can only take the values zero (full-time) or one (part-time), this model is estimated with a probit model.

We use the full-time employment status of the partner to correct for selection into employment groups. In the Netherlands, there is a strong tradition in which one partner works full-time and the other works part-time. Respondents living with a partner who does not work 
and those without a partner are treated as individuals without a full-time employed partner $($ FTpartner $=0)$.

In the second step, the equations of interest are estimated. For part-time and full-time workers, we separately estimate the following three human capital investment equations:

$$
\begin{aligned}
& T P_{i}=a_{1}+b_{1} \text { psych }_{i}+c_{1} H_{R} D_{i}+d_{1} H P W_{i}+e_{1} \text { feedback }_{i}+f_{1} X_{i}+g_{1} I M R_{i}+u_{i 1} \\
& T Q_{i}=a_{2}+b_{2} \text { psych }_{i}+c_{2} \text { HRD }_{i}+d_{2} H P W_{i}+e_{2} \text { feedback }_{i}+f_{2} X_{i}+g_{2} I M R_{i}+u_{i 2} \\
& I L_{i}=a_{3}+b_{3} \text { psych }_{i}+c_{3} H_{R} D_{i}+d_{3} H P W_{i}+e_{3} \text { feedback }_{i}+f_{3} X_{i}+g_{3} I M R_{i}+u_{i 3}
\end{aligned}
$$

where $T P_{i}, T Q_{i}$ and $I L_{i}$ denote the three different types of human capital investments for person $i$ : training participation, number of training courses attended and informal learning measured in fractions of working time. Psych $, H R D_{i}, H P W_{i}$ and feedback $k_{i}$ denote the vectors of explanatory variables, and $X_{i}$ is a vector with control variables. $I M R_{i}$ denotes the Inverse Mills Ratios calculated from the estimation of equation (1).

As $T P$ is a dummy variable, equation (2) is estimated with a probit model. Because $T Q$ is a count variable which only takes a small number of values, equation (3) is estimated with a Negative Binominal Regression model ${ }^{10}$. This model assumes overdispersion (relative to the Poisson case), i.e. that the variance is greater than the mean ${ }^{11}$. Equation (4) is estimated with Ordinary Least Squares (OLS) ${ }^{12}$.

\section{Results}

Table 3 shows that all variables included in the selection equation are highly significant. Being female increases the chance of working part-time with almost 50 percent. When someone has a partner who works full-time, the chance of working part-time is 13 percent higher.

\section{Formal training}

Table 4 reports the estimation results on the determinants of training participation of parttime and full-time workers. The table shows that learning motivation is positively related to training participation for all workers. However, the effect is much greater for part-time workers than for full-time workers. Part-time workers who have a motivation to learn which 
Table 3. First Stage of the Heckman-Type Selection Correction Model

\begin{tabular}{lrrr}
\hline \hline & Part-Time & \\
coefficients & marginal effects \\
Age & 0.021 & $* * *$ & 0.007 \\
& $(0.005)$ & & \\
Female & 1.484 & $* * *$ & 0.484 \\
& $(0.120)$ & & \\
Years of education & -0.087 & $* * *$ & -0.028 \\
& $(0.021)$ & & \\
Full-time status partner & 0.382 & $* * *$ & 0.130 \\
& $(0.121)$ & & \\
Number of children & 0.160 & $* * *$ & 0.052 \\
& $(0.046)$ & & \\
Constant & -1.136 & $* * *$ & \\
& $(0.423)$ & & \\
\hline Number of observations & 864 & & \\
Pseudo R-squared & 0.2701 & & \\
Log likelihood & -391.673 & & \\
\hline \hline
\end{tabular}

Note: Female and Full-time status Partner are dummy variables equal to one when someone is female and has a partner working full-time respectively, and zero otherwise. Marginal effects are evaluated at the sample means of the data.

* significant at $10 \%$, ** significant at $5 \%$, *** significant at $1 \%$

is one standard deviation above the average have almost 13 percent more chance of having attended a training course during the last two years compared to an increased probability of about 5 percent for full-time workers. The impact of imagination on training participation is only significant for part-time workers.

Human resource development practices, on the other hand, only stimulate training participation of full-time workers, although there is a weakly significant effect of performance interviews on training participation of part-time workers. Full-time workers with performance interviews have 15 percent more chance of attending training. When full-time workers have a personal development plan, their chances of participating in training are also 15 percent higher. Remarkably, having a career plan has a negative effect. However, this effect is only weakly significant. We do not find many effects of high performance workplaces on training participation of part-time or full-time workers ${ }^{13}$. Only performance payments are stimulating training participation of full-time workers (at the 10 percent significance level). Feedback does not play a role in explaining training participation of both part-time and full-time workers. 


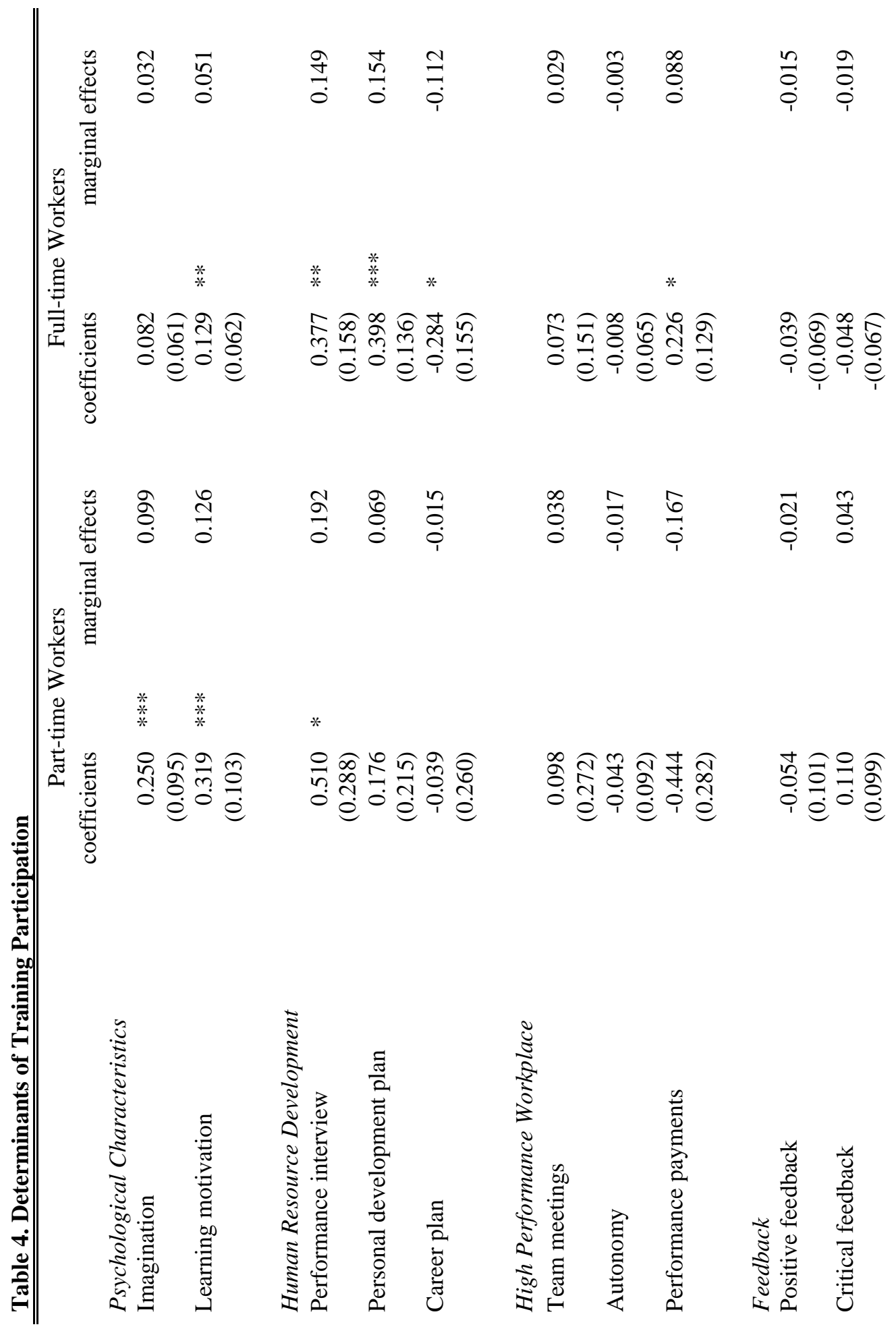




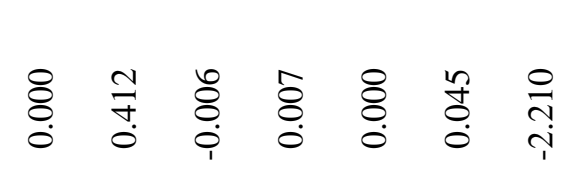

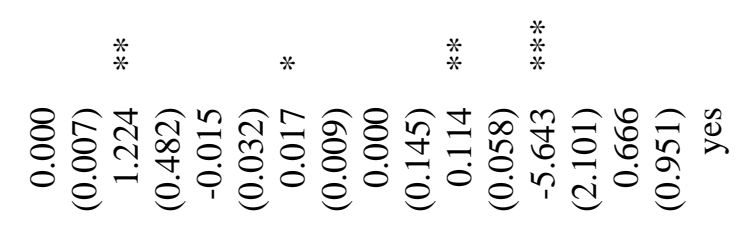

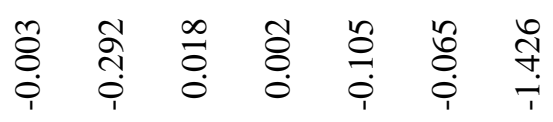

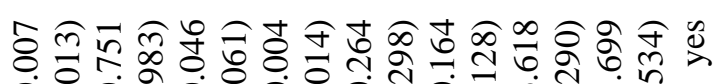

$$
\begin{aligned}
& \text { i }
\end{aligned}
$$

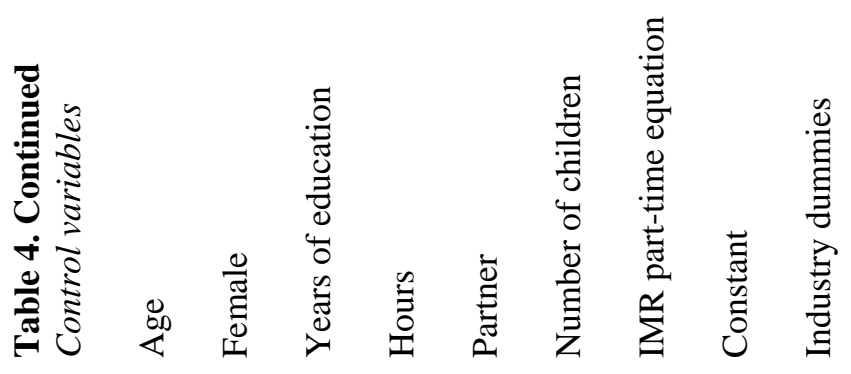

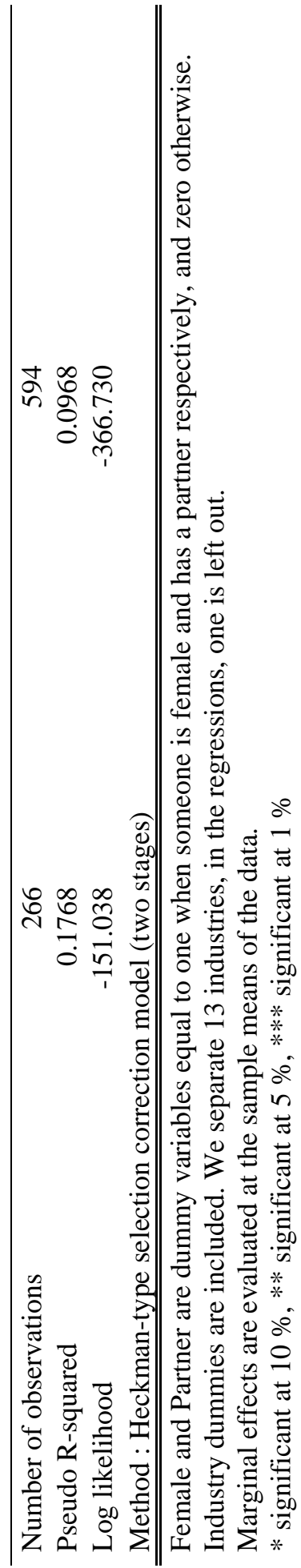


As the IMRs of part-time workers are not statistically significant, selection does not seem to play a role for part-time workers. This is in contrast to the test results shown for full-time workers. Since the IMRs are highly significant, we conclude that full-time workers' training participation is affected by a selection bias.

Furthermore, it is remarkable that control variables which are often used to explain training participation, such as workers' age, years of education and number of children, do not significantly influence workers' training participation. Gender is the only exception. Fulltime working women have an increased probability of training participation. The observation that these common training determinants are not significant when the characteristics of workers and employers are included, indicates that one should be careful in relating basic characteristics such as age, gender and educational level to training behaviour, without including the workers' psychological characteristics and the firms' human resource practices.

Table 5 shows the estimation results of the determinants of the number of training courses workers participated in. This allows us to distinguish among the workers who participated in formal training. The table shows that psychological characteristics are not only related to training participation, but also to the number of training courses part-time workers attend. Full-time workers who are highly motivated to learn have a stronger tendency to attend more training courses. The effect of learning motivation on the number of training courses attended is similar for part-time and full-time workers. Furthermore, the number of training courses of full-time workers is influenced by human resource development practices, whereas those of part-time workers are not: Performance interviews and personal development plans affect the number of training courses of full-time workers positively. The variables related to the high performance workplace and the feedback variables do not influence the number of training courses part-time and full-time workers attend ${ }^{14}$.

Furthermore, table 5 shows that selection plays a role for full-time workers. The Inverse Mills Ratios (IMRs) are significant at the 10 percent level. Since the IMRs are not significant for part-time workers, we assume that there are no factors which influence both the employment status and human capital behaviour of part-time workers. 


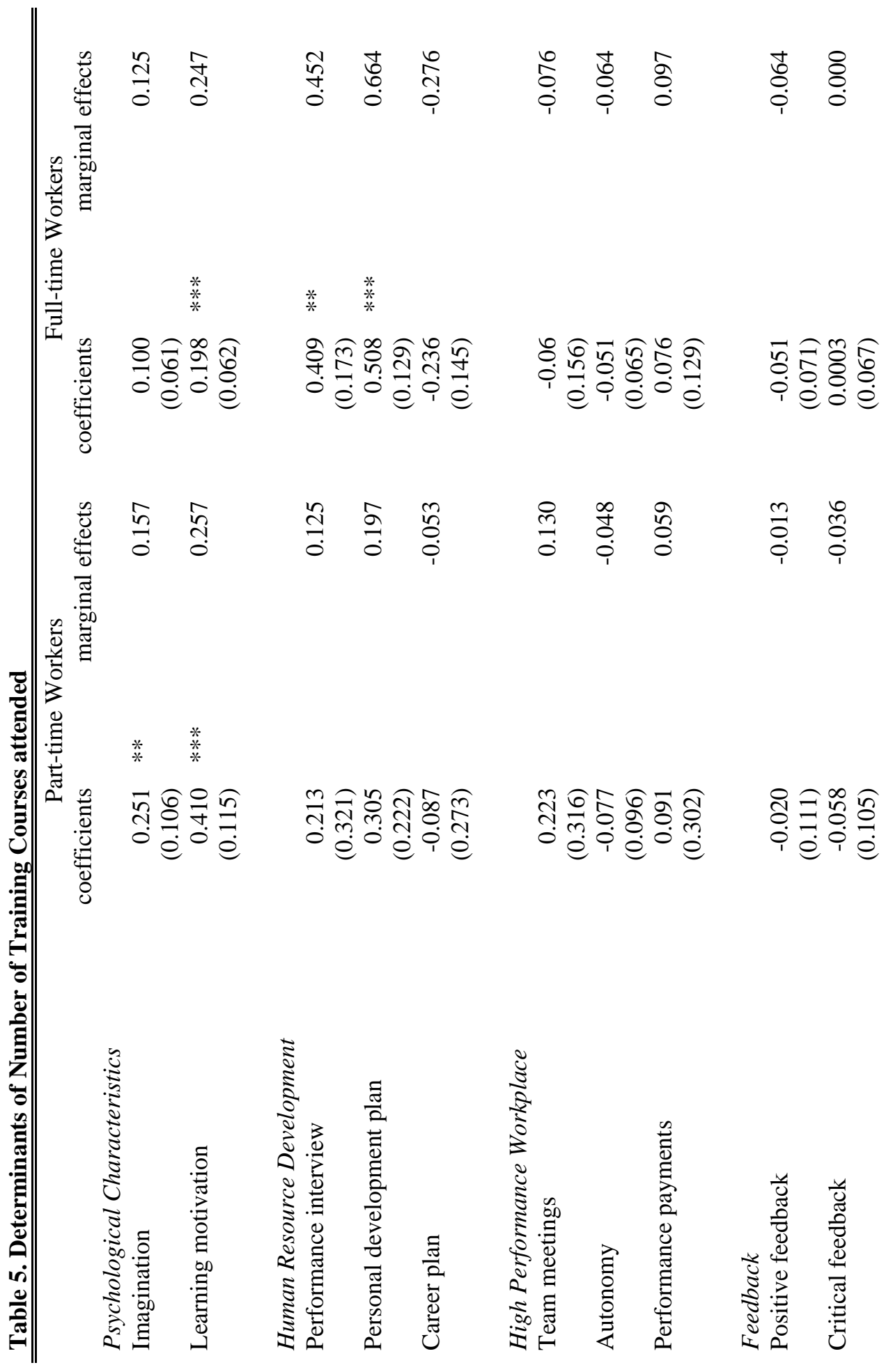






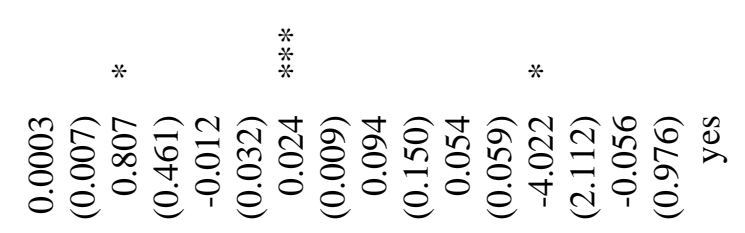

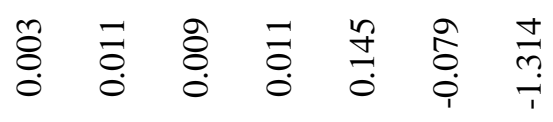

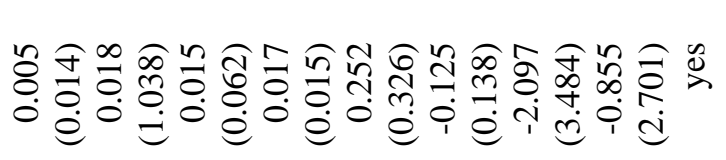

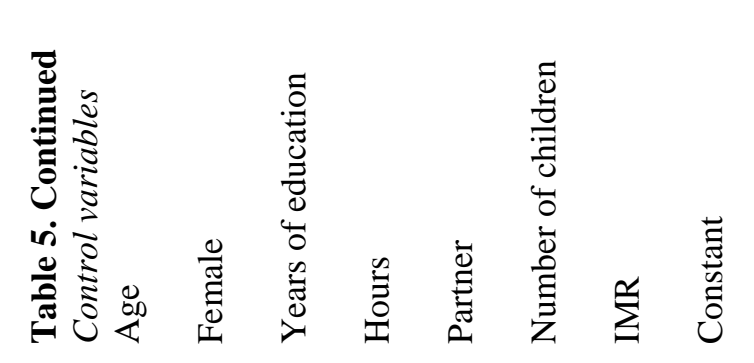

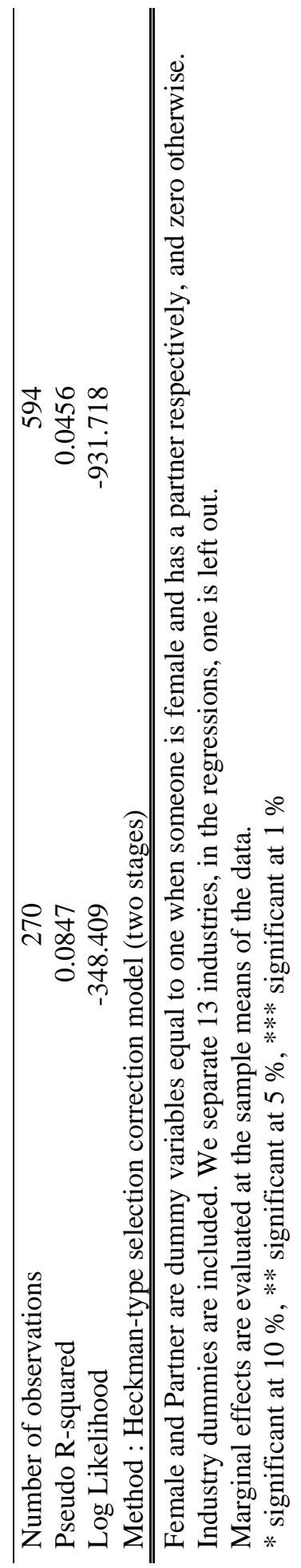


Table 6. Determinants of Informal learning (as fraction of working time)

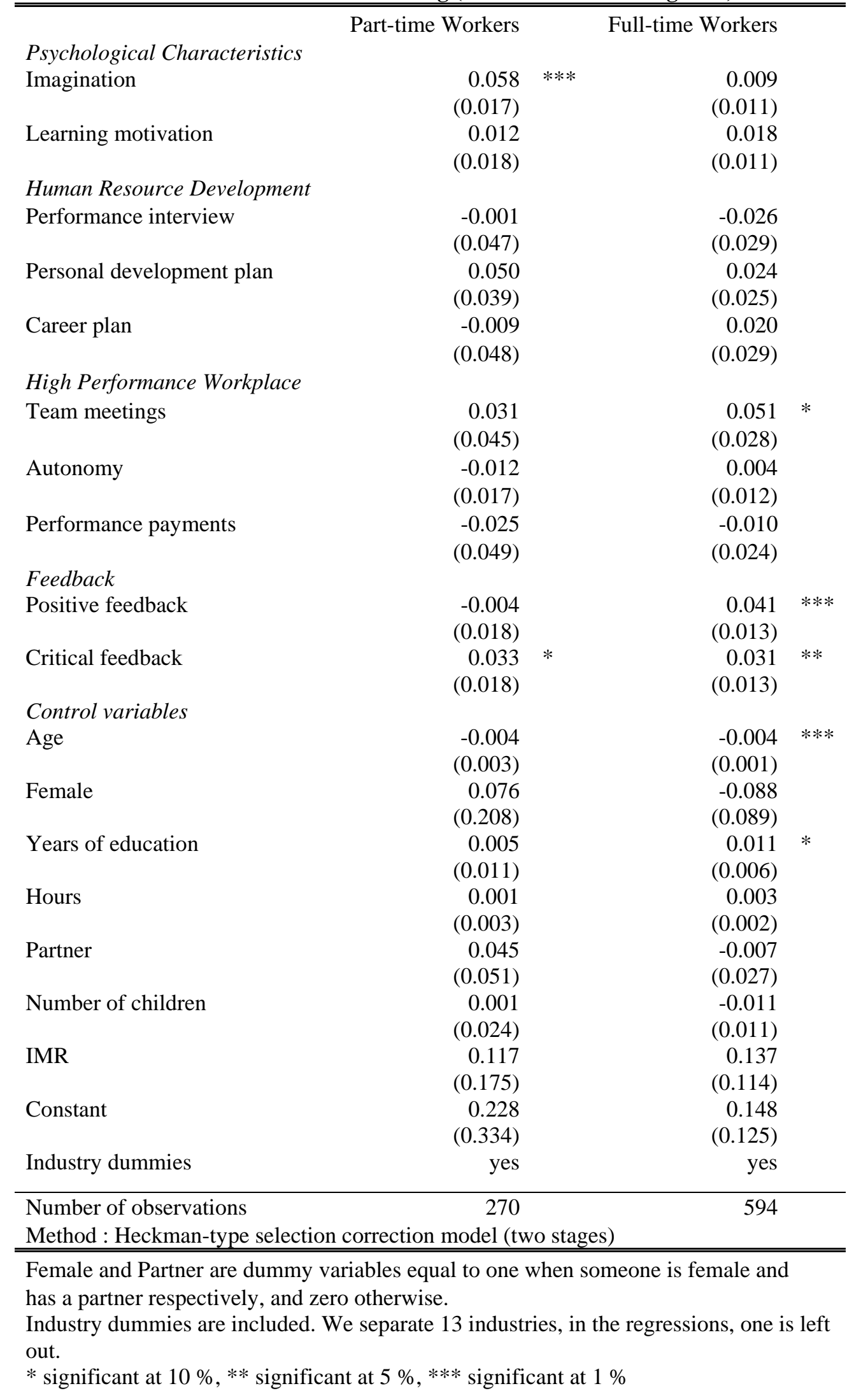


Informal learning

Table 6 shows the estimation results on the determinants of informal learning, as a fraction of working time ${ }^{15}$. The only explanatory variable which has a strongly significant influence on part-time workers' informal learning behaviour is imagination. Part-time workers with an imagination of their future development one standard deviation higher than the average worker spend on average almost 6 percent more working time on tasks from which they learn. On the contrary, full-time workers' informal learning behaviour does not depend on their capacity to imagine their future development or on their learning motivation. Although human resource development and high performance workplace variables do not affect informal learning of either part-time or full-time workers $^{16}$, the latter are positively influenced by the feedback they get at work. Both positive and critical feedback positively influence the fraction of working time in which full-time workers learn informally, whereas we only find a weakly significant effect of critical feedback on informal learning for parttime workers.

Since determinants of informal learning have hardly been analyzed in economic literature, we will also briefly comment on the control variables. As can be seen in Table 6, age has a negative effect on informal learning for full-time workers. Full-time workers who are one year older spend on average around 0.4 percent less on informal learning. Years of education only has a weakly significant positive effect on full-time workers' informal learning. Other control variables do not affect the fraction of working time spend on informal learning. Since the IMRs are not significant in both the part-time and full-time informal learning equations, there seems to be no selection for both types of workers ${ }^{17}$.

Combining all forms of human capital investments, we can conclude that HRM policy is the main factor driving the human capital investments of full-time workers. Table 4 shows that full-time workers' chance to participate in training largely depends on the HRM practices of the firm they are working for. The role of HRM practices implies that in firms with good HRM practices, the incidence of training participation is larger. Worker characteristics do not seem to play a big role. However, this changes when we analyze the number of training courses in which full-time workers participate. Even though the two variables that identify training oriented HRM practices are still significant, learning motivation becomes important as well. Thus, the large pool of workers that receive training is divided by motivation. Those workers with high motivation distinguish themselves from other full-time workers by 
attending more training courses. Table 6 shows that informal learning behaviour of full-time workers is mainly explained by age and the feedback policy of the firm.

For part-time workers, the results are different. Table 4 shows that worker characteristics determine whether part-time workers participate in training or not. Even in companies that have elaborate HRM practices, only those workers who are motivated to learn and have a clear idea about their further development get trained. For part-time workers, not only training participation, but also the number of training courses attended is driven by these two variables.

The fraction of working time in which workers perform tasks from which they learn is fairly equal for part-time and full-time workers. However, while full-time workers' informal learning behaviour depends most on the feedback system of the firm where they are employed, this does not hold for part-time workers. Even though part-time workers get more feedback than full-time workers, for part-time workers, the effect of critical feedback is only weakly significant. The positive feedback part-time workers get at their work, is not related to their further development. Imagination of further development is the only factor which strongly stimulates informal learning behaviour of part-time workers. Again, personal drive seems to be most important in explaining human capital investments of part-time workers.

It is remarkable to note that for part-time workers the determinants of formal training and informal learning are fairly similar, whereas for full-time workers there is a clear difference between formal training and informal learning determinants. Even though full-time workers are on average influenced mostly by human resource practices, human resource development such as performance interviews and personal development plans only seem to affect their formal training behaviour, whereas informal learning behaviour is stimulated by feedback in the workplace. All forms of human capital investments of part-time workers are driven by workers' characteristics such as imagination of further development and learning motivation.

\section{Conclusion}

In this paper, we analyzed the differences in the determinants of participation in both formal training and informal learning between part-time and full-time workers. Human capital theory 
expects both workers themselves and firms to be less willing to invest in part-time workers. We found that human capital investments of part-time workers are mainly supply lead. Psychological characteristics - imagination of one’s own future development being the most important one - positively influence both formal training and informal learning. Human resource practices are hardly of any influence on part-time workers' further investments in human capital development. This is in sharp contrast with the determinants of full-time workers' participation in formal training and informal learning. Whereas psychological characteristics only affect full-time workers' formal training incidence, human resource practices are important for both formal training and informal learning. Formal training is stimulated in particular by human resource development practices such as performance interviews and personal development plans. Informal learning is positively affected by both positive and critical feedback in the workplace. It is remarkable that although part-time workers receive more feedback than full-time workers, we do not find a strong positive effect of feedback on informal learning behaviour of part-time workers. Probably, the feedback is not related to their further development.

Concluding, the differences in human capital investments between part-time and full-time workers are mainly demand lead. Full-time workers are positively affected by human resource practices of the firm in which they are employed. However, firms do not effectively stimulate part-time workers in a similar way. Part-time workers can only partly compensate the lack of firm support when they have a high learning motivation and imagination of their future development. 


\section{References}

Arthur J.B. (1994) "Effects of Human Resource Systems on Manufacturing Performance and Turnover”, Academy of Management Journal, 37: 670-687.

Beblo M., Beninger D., Heinze A. and Laisney F. (2003) “Measuring Selectivity-Corrected Gender Wage Gaps in the EU”, ZEW Discussion Paper, 03-74

Becker G. (1964) Human Capital: a Theoretical and Empirical Analysis, with Special Reference to Education, New York: NBER.

Becker B.E. and Huselid M.A. (1998) "High performance work systems and firm performance: a synthesis of research and managerial implications”. In: Ferris G.R. (ed.), Research in Personnel and Human Resources, 16, Stamford, CT: JAI Press: 53-101.

Birdi K., Allan C. and Warr P. (1997) “Correlates and perceived outcomes of four types of employee development activity”, Journal of Applied Psychology, 82: 845-857.

Borghans L., Golsteyn B. and De Grip A. (2007) “Werkend leren”, ESB 92: 260-263.

Cameron A.C. and Trivedi P.K. (1998) Regression Analysis of Count Data, Cambridge: Cambridge University Press.

Colquitt J.A., LePine J.A. and Noe, R.A. (2000) “Towards an integrative Theory of Training Motivation: A Meta-Analytic Path Analysis of 20 years of research”, Journal of Applied Psychology, 85: 678-707.

Colquitt J.A. and Simmering M.S. (1998) "Conscientiousness, goal orientation, and motivation to learn during the learning process: A longitudinal study”, Journal of Applied Psychology, 83: 654-665.

De Grip A., Hoevenberg, J. and Willems E. (1997) “Atypical employment in the European Union”, International Labour Review, 136: 49-71. 
DellaVigna S. and Paserman M.D. (2005) “Job search and impatience”, Journal of Labor Economics, 23: 527-588.

Facteau J.D., Dobbins G.H., Russsell J.E.A., Ladd R.T. and Kudisch J.D. (1995) “The influence of general perceptions of the training environment on pretraining motivation and perceived training transfer”, Journal of Management, 21: 1-25.

Fersterer J. and Winter-Ebmer R. (2003) “Smoking, discount rates, and returns to education”, Economic Educational Review, 22: 561-566.

Golsteyn B. (2007) The Ability to Invest in Human Capital. PhD thesis, Maastricht: University of Maastricht.

Greenhalgh C. and Mavrotas G. (1996) “Job training, new technology and labour turnover”, British Journal of Industrial Relations, 34: 131-150.

Ichniowski C., Shaw K. and Prennushi G. (1997) "The effects of human resource management practices on productivity: A study of steel finishing lines”, American Economic Review, 87: 291-312.

Kahneman D. and Tversky A. (1979) "Prospect theory: An analysis of decisions under risk”, Econometrica, 47: 313-327.

Lynch L.M. and Black I.S. (1998) “Beyond the Incidence of Employer-Provided Training”, Industrial and Labor Relations Review, 52: 64-81.

Maximiano S. and Oosterbeek H. (2007) “On the determinants of workers' and firms' willingness to train”, mimeo.

MacDuffie J.P. (1995) "Human resource bundles and manufacturing performance: Organizational logic and flexible production systems in the world auto industry”, Industrial and Labor Relations Review, 48: 197-221. 
McFarland C., and Miller D.T. (1994) "The framing of relative performance feedback: Seeing the glass as half empty or half full”, Journal of Personality and Social Psychology, 66: 1061-1073.

Munasinghe L., and Sicherman N. (2000) "Why do dancers smoke? Time preference, occupational choice, and wage growth”, NBER working paper 7542.

Noe R.A., and Schmitt N. (1986) “The influence of trainee attitudes on training effectiveness: Test of a model”, Personnel Psychology, 39: 497-523.

Osterman P. (1994) "How common is workplace transformation and who adopts it?" Industrial and Labor Relations Review, 47: 173-188.

Thaler R.H. (1999) "Mental Accounting Matters”, Journal of Behavioral Decision Making, 12: 183- 206.

Tilly C. (1996) "Half a Job: Bad and Good Part-Time Jobs in a Changing Labor Market”, PhD Thesis, Philadelphia: Temple University Press.

Webster J. and Martocchio J.J. (1993) “Turning Work into Play: Implications for Microcomputer Software Training”, Journal of Management, 19: 127-146.

Wood S. (1999) “Human resource management and performance” International Journal of Management Reviews, 1: 367-413.

Wooldridge J.M. (2002) Econometric Analysis of Cross Section and Panel Data, Cambridge: The MIT Press.

Youndt M.A., Snell S.A., Dean J.W. jr. and Lepak D.P. (1996) "Human Resource Management Manufacturing Strategy and Firm Performance”, Academic of Management Journal, 39: 836-866. 


\section{Notes}

${ }^{1}$ Another stream of literature focuses on psychological characteristics that influence training participation through training motivation. For an overview of psychological characteristics on training motivation, see Colquitt, LePinne and Noe (2000). Examples are the role of anxiety (e.g. Webster \& Martocchio, 1993), locus of control (e.g. Noe and Schmitt, 1986) and conscientiousness (e.g. Colquitt \& Simmering, 1998 on training motivation.

${ }^{2}$ When analyzing the determinants of both formal training and informal learning with contractual working hours in stead of actual working hours, our findings are confirmed. Within the group of part-time workers the contractual working hours become significant for both formal training and informal learning. For full-time workers, even more HRM practices are significantly positive related to formal training. Thus the results of the model with contractual working hours, strengthens our main conclusions.

${ }^{3}$ Using the part-time work definition used in the DNB Household Survey leads to the same results as the findings we present in this paper.

${ }^{4}$ In the first wave of the Life-Long-Learning Survey in 2004, this percentage is about 30 percent.

${ }^{5}$ The hours variable takes account of the effect that more working time increases the benefits of human capital as stated by human capital theory.

${ }^{6}$ Since the Survey does not provide information on firm size, we cannot include this in the analysis.

${ }^{7}$ We combined two industries because of the small numbers of observations. It concerns industries 1 (agriculture \& extracting minerals) and 3 (energy \& water supply).

${ }^{8}$ We also extended our selection model to control for selection into (un)employment. However, this did not affect our results.

${ }^{9}$ As ML estimation relies on the joint normality assumption of the errors in the selection equation and the equation of interest, misspecification of one of the equations results in inconsistency. Although, the two-step estimator is less efficient if both equations are correctly specified, the estimator is less sensitive to inconsistency because it only relies on conditional moments (cf. Beblo, 2003).

${ }^{10}$ Wooldridge (2002) stated that when a count variable only takes a small number of values count data models are more appropriate than Tobit models (page 520).

${ }^{11}$ We use the Lagrange Ratio test to test for overdispersion. With a LR statistic of 49.638, we are sure that the Negative Binominal Regression Model is preferred above the Poisson model. See: Cameron and Trivedi (1998).

${ }^{12}$ As all equations include the same regressors, seemingly unrelated regression models are not needed (even if the three errors are correlated, OLS and GLS will provide identical estimators) and simultaneous models fail identification.

${ }^{13}$ The three variables that form the category high performance workplace are not jointly significant either.

${ }^{14}$ The variables measuring high performance workplace are not jointly significant either.

${ }^{15}$ We also estimated the explanatory variables on the hours spend on tasks from which workers learn. Since the results of this estimation are comparable to the one in which informal learning is measured in fractions, we decided not to include these results explicitly in the paper.

${ }^{16}$ The human resource development practices are not jointly significant either, nor are the variables measuring high performance workplace.

${ }^{17}$ Results do not change if we estimate a simple OLS model for informal learning. 